\title{
Gender-related voice problems in transsexuals - therapeutical demands
}

\author{
Problemy głosowe związane z płcią u transseksualistów - aspekty terapeutyczne
}

\author{
Maciej Misołek1, Ewa Niebudek-Bogusz² , Joanna Morawska², Bogusława Orecka ${ }^{1}$, \\ Wojciech Ścierski ${ }^{1}$, Grażyna Lisowska ${ }^{1}$
}

${ }^{1}$ Department of Otorhinolaryngology and Laryngological Oncology in Zabrze, Medical University of Silesia, Katowice, Poland ${ }^{2}$ Nofer Institute of Occupational Medicine, Department of Audiology and Phoniatrics, Eódź, Poland

\begin{abstract}
The paper presents a case study of a transsexual patient who underwent a voice pitch elevation surgery performed in Poland for the first time. The human voice is a reflection of the working of hormones and human psyche. This fact is of particular importance in transsexualism, a disorder consisting in incongruence between the individual's biological sex and their identified gender. For many transsexual people, especially of the MTF (male to female) type, who have undergone hormonal and surgical sex change, the voice still presents a major problem, causing difficulties in everyday life. Hormonal treatment does not influence feminisation of the larynx. In the described MTF case, the patient's low androphonic voice was perceived as a male voice.

In order to feminise the patient's voice a phonosurgical procedure was performed: the length of the vibrating portion of the vocal folds was shortened by over $50 \%$ of their total length by means of suturing of the anterior part of the vocal fold. As a result of the surgical treatment the pitch of voice was raised considerably, with $\mathrm{F} 0$ of spoken voice increased from $109 \mathrm{~Hz}$ to $209 \mathrm{~Hz}$. The voice range also changed towards female tones, from 59-146 Hz to 148-343 Hz. Pitch elevation positively influenced the patient's subjective voice assessment: total score of the Voice Handicap Index (VHI) improved from 99 to 19 points, and the score of its emotional sub-scale: 39 and 2 points, respectively. The described case of a surgical male-to-female voice change presents one of the dilemmas faced by modern medicine.

(Endokrynol Pol 2016; 67 (4): 452-455)
\end{abstract}

Key words: gender vocology; transsexual; androphonia, phonosurgery

\section{Streszczenie}

Przedstawiono przypadek pacjentki transseksualnej, u której po raz pierwszy w Polsce przeprowadzono zabieg chirurgiczny zmiany głosu z męskiego na żeński. Głos ludzki — drugorzędowa cecha płciowa — jest odzwierciedleniem działania hormonów i psychiki. Fakt ten nabiera szczególnego znaczenia w transseksualizmie, zaburzeniu polegającym na niezgodności płci biologicznej z płcią psychiczną. Dla wielu osób transseksualnych, szczególne w postaci transseksualizmu M/K (mężczyzna/kobieta) po hormonalnej i chirurgicznej zmianie płci biologicznej ważnym problemem nastręczającym trudności w życiu codziennym pozostaje głos, gdyż leczenie hormonalne nie wpływa na feminizację krtani - aparatu głosowego. W opisywanym przypadku niski androfoniczny głos pacjentki był percepowany przez otoczenie jako męski. W celu feminizacji głosu wykonano leczenie fonochirurgiczne: skrócono fałdy głosowe o ponad 50\% ich długości poprzez założenie szwów zespalających $\mathrm{w}^{1}$ 1/2 przedniej części głośni. W wyniku zabiegu podwyższono znacząco głos: przedoperacyjna częstotliwość głosu mówionego wyraźnie przesunęła się po operacji w górę z wartości $109 \mathrm{~Hz}$ do $209 \mathrm{~Hz}$. Zakres głosu także zmienił się w kierunku tonów żeńskich z 59-146 Hz do 148-343 Hz. Zmiana wysokości głosu u pacjentki wpłynęła pozytywnie na jej subiektywną ocenę głosu: wynik kwestionariusza VHI (Voice Handicap Index) poprawił się z 99 pkt — przed operacją do 19 pkt — po operacji. Na poprawę jakości życia wskazuje także spadek problemów emocjonalnych związanych z głosem, ocenianych za pomocą podskali emocjonalnej VHI, której wynik wynosił odpowiednio: 39 pkt przed vs. 2 pkt po operacji.

Prezentowany przypadek chirurgicznej zmiany głosu z męskiego na żeński, dokonany po raz pierwszy w warunkach polskich, przedstawia jeden z dylematów stawianych przed współczesną medycyną. (Endokrynol Pol 2016; 67 (4): 452-455)

Słowa kluczowe: transseksualizm; androfonia; fonochirurgia

\section{Introduction}

The larynx - the apparatus of voice - is a sex hormonal target. Voice is a secondary sex characteristic, a powerful feature discriminating gender. The ancients were well aware of it; for example, in 400 BC Aristotle described the effect of castration on a songbird. A perfect example of the impact of sex hormone on voice are castrati, who in the Middle Ages sang in highpitched, feminine voices in the chapel choirs [1]. The voice is characterised by its intensity, harmonics, and frequency of glottal vibrations - the main distinguish- 
ing feature of male and female voices [2]. To allow the castrato to have a feminine voice, the castration had to be performed pre-pubertally and before any secretions of testosterone appeared. The castrati voice had a female frequency and harmonics, but the intensity and power of a male voice. Therefore, their range of voice was impressive: 3-4 octaves (normal value: 1.5 ) and maximal phonation time: 120 seconds (normal value: 20 seconds). Even at that time, the importance of the definitive and indelible hormonal influence of testosterone was recognised, including its impact on the voice apparatus [3].

It was stressed that the voice is at the crux of the hormonal world and the psyche [1]. This fact can be particularly observed in transsexual subjects $[2,4,5]$. Transsexualism is a condition in which a person believes that his or her psychological gender is incongruent with their anatomic gender [6]. In diagnostic terms, the socalled gender dysphoria is categorised as a gender identity disorder encoding transsexualism as F 64.0 within the International Classification of Diseases ICD-10.

Transsexual people experience inconsistency between their mental sense of sex and their biological, social, metrical, and legal gender. They feel the urge to align their body with their identified sex. The World Professional Association of Transgender Health [cited after 7] has outlined the standard steps for medical assistance in transsexualism: 1. diagnosis excluding mental disorders and other sexual orientation disorders (for example transvestitism); 2 . hormone therapy to induce sex characteristics of the sex one reckons oneself to belong to; 3 . sex reassignment surgery - a procedure (or a number of procedures) altering a transsexual person's physical appearance and function of their existing sexual characteristics to resemble that of their identified gender; and 4. legal regulation - changing sex in official documents connected with the change of name.

The prevalence of transsexualism in Europe is high and seems to be have been increasing since the 1960s
[8]. There are two main types of transgender individuals. A male-to-female (MTF) transsexual is a person seeking to transition from their birth male gender to the female gender, and a female-to-male (FTM) transsexual is a person seeking to transition from their birth female gender to the male gender. For most European countries the ratio of MTF transsexuals is two or more times higher than of FTM transsexuals. The prevalence of MTFs is estimated to be between 1:34000-1:200000 and for FTMs 1:11900-1:45000 [9].

Male-to-female transsexuals are more likely to seek medical services for vocal intervention because of their low, androphonic voice. Hormone replacement therapy applied after puberty does not help to raise vocal pitch and make the voice sound more feminine. This was the case in the presented patient, who underwent a voice pitch elevation surgery performed in Poland for the first time.

\section{Case report}

Patient M.S., a 25-year-old male-to-female transsexual who underwent medical and legal procedures of gender transition (described above), was seeking laryngological help to feminise her voice. The thyroid chondroplasty was performed to reduce the silhouette of the male thyroid cartilage (Adam's apple). The procedure changed the masculine protrusion to a feminine straight neck, but did not have any impact on voice feminisation. She was qualified to phonosurgical procedure: glottoplasty. Before surgery a complex phoniatric examination was performed including: laryngovideostroboscopy, acoustic analysis of the voice, Maximum Phonation Time (MPT) measurement, and subjective voice evaluation (Voice Handicap Index) [1]. In the laryngovideostroboscopy a typical male-type larynx with long vocal folds was observed (Fig. 1A). The fundamental frequency of laryngeal tone F0 (pitch of voice) was $116 \mathrm{~Hz}$, the average frequency of spoken voice $109 \mathrm{~Hz}$, and the range of spoken voice was 59-146

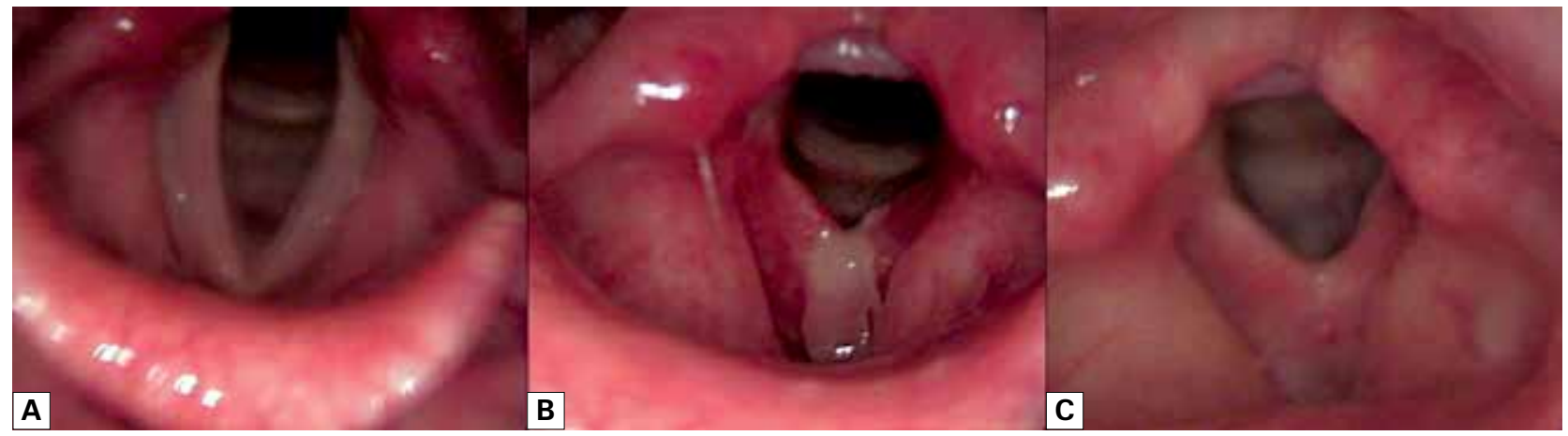

Figure 1. Imaging of larynx: A. Pre-surgery; B. Post-surgery, with granulation present; C. Post-surgery, entirely healed Rycina 1. Obraz krtani: A. przed operacja; B. po operacji, z procesem ziarninowania; C. po operacji, catkowite wygojenie 
Table I. Comparison of the pitch of voice pre- and post-surgery

Tabela I. Porównanie wysokości głosu przed i po operacji

\begin{tabular}{lcccc}
\hline Parameters & Fundamental frequency & Fo range & Average frequency of spoken voice & Spoken voice range \\
\hline Pre-surgery & $116 \mathrm{~Hz}$ & $111-121 \mathrm{~Hz}$ & $109 \mathrm{~Hz}$ & $59-146 \mathrm{~Hz}$ \\
\hline Post-surgery & $261 \mathrm{~Hz}$ & $196-298 \mathrm{~Hz}$ & $209 \mathrm{~Hz}$ & $148-343 \mathrm{~Hz}$ \\
\hline
\end{tabular}
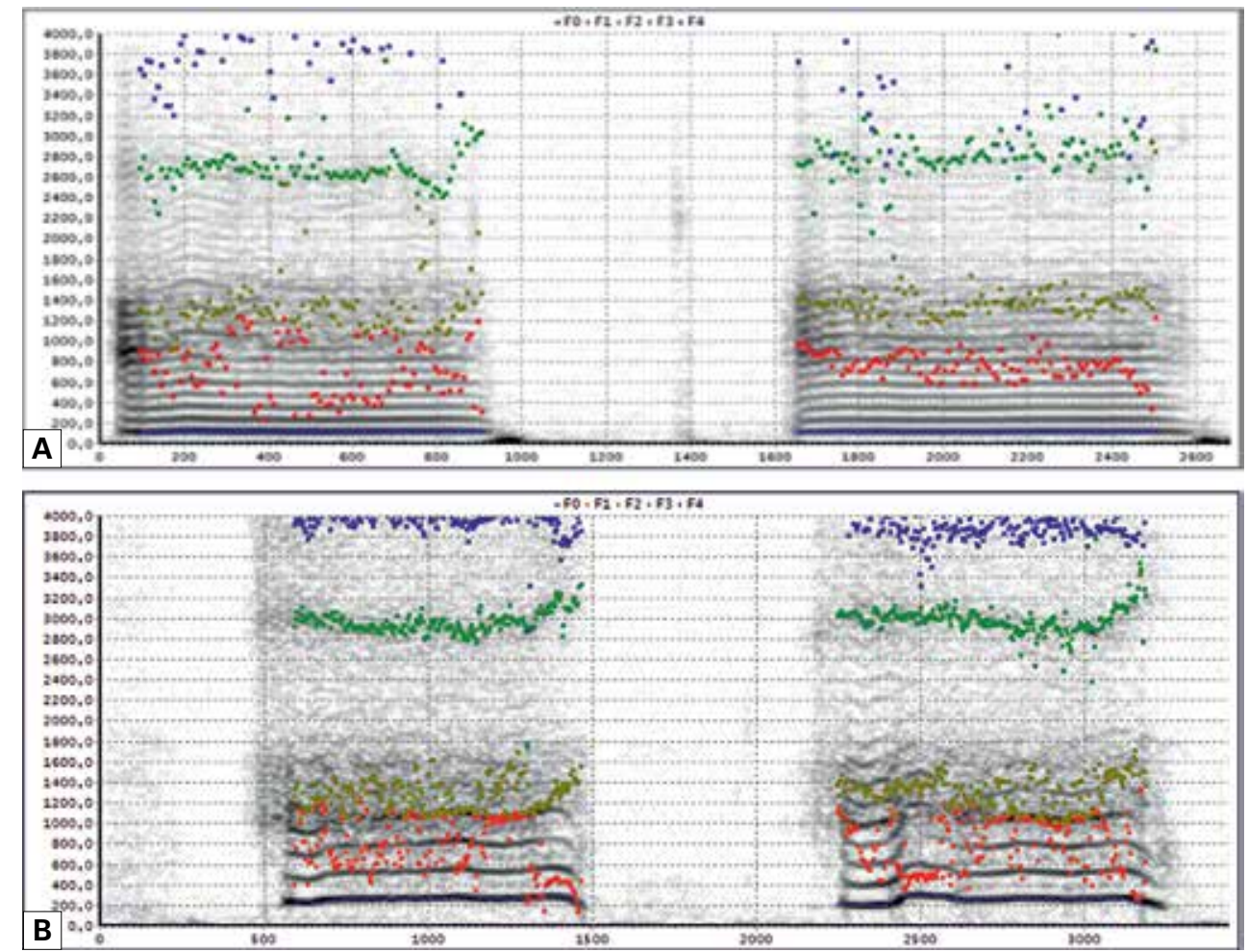

Figure 2. Formant structure analysis of " $a$ " vowel A. Pre-surgery; B. Post-surgery

Rycina 2. Analiza struktury formantowej przez i po operacji

$\mathrm{Hz}$ (Table I). Maximum Phonation Time, the average of three consecutive measurements, was 12 seconds. In the subjective voice evaluation test VHI the patient scored the total of 99 points indicating a severe voice handicap, especially in the emotional sphere of life: 39 points in the emotional sub-scale of VHI (Table II). Before surgery the patient started voice therapy sessions, which were aimed at raising the pitch of voice as well as helping the patient gain a broad understanding of the voice and communication feminisation process. The voice therapy techniques used included: raising the position of the larynx, enhancing resonance, and raising the frequency of formants, in particular F3, which determine the timbre of the voice. Additional exercises focused on improving intonation, articulation, prosody, gestures, and mimics. Voice therapy did not produce satisfactory results and the patient was qualified for surgical treatment with a Wendler glottoplasty technique. The procedure consists of the $\mathrm{CO} 2$ laser de-epithelialisation of the anterior commissure along with the anterior third of the two vocal folds, the suturing of the two vocal folds with two resorbable threads. After the post-operative glottal wound had entirely healed and granulation receded (Fig. 1B), a phoniatric examination was performed according to the protocol described above. The vocal folds were considerably shorter (Fig. 1C). The length of the vibrating portion of the vocal folds was shortened by over $50 \%$ of their total length. As a result of the surgical treatment the pitch of voice was raised considerably to $261 \mathrm{~Hz}$ and the speaking voice range was $148-343 \mathrm{~Hz}$, which meant the voice was within the range characteristic for a female voice (Table I). Even though the patient participated in only two speech therapy sessions, the formant structure of the voice also changed - with $\mathrm{F} 1$ at $795 \mathrm{~Hz}$ post surgery vs. 739 $\mathrm{Hz}$ pre surgery and F3 at $2959 \mathrm{~Hz}$ post surgery vs. 2716 $\mathrm{Hz}$ pre surgery (Fig. 2). Maximum Phonation Time was shorter (nine seconds) due to the narrower glottal area. 
Table II. Comparison of VHI results pre- and post-surgery Tabela II. Porównanie wyników VHI przed i po operacji

\begin{tabular}{lcccc}
\hline Parameters & VHI $-\mathbf{T}$ & VHI $-\mathbf{F}$ & VHI $-\mathbf{E}$ & VHI - P \\
\hline Pre-surgery & 99 points & 38 points & 39 points & 22 points \\
\hline Post-surgery & 19 points & 10 points & 2 points & 7 points \\
\hline
\end{tabular}

However, the patient did not report any breathing difficulties. The total score of the VHI was significantly lower - 19 points, with an emotional sub-scale result of 2 points (Table II), indicating a substantial improvement in voice self-assessment.

\section{Discussion}

The voice is an important gender marker [3]. There are a number of features that determine the perception of voice as feminine, namely: pitch - fundamental frequency of laryngeal tone (F0), two times higher in women than in men; formant structure characteristic for female voice; timbre; and rising intonation at the end of a sentence [10]. Achieving a feminine voice is typically an important component of the overall gender transition process of male-to-female transsexuals, in whom the physical appearance of the body and the voice are incongruent. The hormone replacement therapy with MTF individuals, used after puberty, fails to change male features of the larynx structure and does not make the voice sound more feminine. Their voice is frequently perceived as the male voice due to the low pitch - the fundamental frequency of laryngeal tone. A dividing line for male versus female voice perception is the fundamental frequency of approximately $155-160 \mathrm{~Hz}$ [11]. In the presented case of a female MTF the voice of the patient was extremely low: the average frequency of spoken voice was $109 \mathrm{~Hz}$ and the fundamental frequency of laryngeal tone was $116 \mathrm{~Hz}$. Therefore, the pitch of voice was the reason for her voice to be perceived as a male voice. In daily life this fact was the cause of multiple psychological and emotional problems. The inconsistency between the achieved female gender and the features of voice drastically decreased her quality of life, which was reflected in the poor results of the Vocal Handicap Index: the total score of the VHI was 99 points and the score of emotional sub-scale of VHI was 39 points. The distress associated with this condition caused the patient to seek laryngological intervention.

Before the surgical treatment the patient participated in voice fitting sessions under the supervision of a speech therapist. The applied voice therapy yielded no positive results. The intonation, gestures, and mimics (the body speech) characteristic for a female were well controlled by the patient; nonetheless, her very low voice was still perceived as a male voice.

The surgical treatment with a Wendler glottoplasty endoscopic technique, performed in Poland for the first time, significantly raised the vocal pitch in the presented MTF individual.

The length of the vibrating portion of the vocal folds was shortened by over $50 \%$ of their total length by means of suturing of the anterior part of vocal fold after precise rim deep epithelisation. As a result of the surgical treatment the pitch of voice was raised considerably: the frequency of spoken voice was clearly raised after the surgery, from $109 \mathrm{~Hz}$ to $209 \mathrm{~Hz}$. The voice range also changed towards female tones, from $59-146 \mathrm{~Hz}$ to $148-343 \mathrm{~Hz}$. All the above mentioned changes resulted in a decline in voice-related emotional problems, assessed by means of the VHI emotional subscale, which decreased from 39 points before surgery to 2 points after surgery. These results influenced an improvement in the patient's overall quality of life.

\section{Conclusions}

The acquiring a sex-appropriate voice is an imperative part of the transition toward gaining acceptance in the transsexual's new gender.

\section{References}

1. Rubin JS, Sataloff RT, Korovin GS (eds.): Diagnosis and treatment of voice disorder, 4th edition, Plural Publishing, San Diego 2014.

2. Holmberg EB, Oates J, Dacakis G et al. Phonetograms, aerodynamic measurements, self-evaluations, and auditory perceptual ratings of male-to-female transsexual voice.

3. J Voice 2010; 24: 511-522. DOI:10.1016/j.jvoice.2009.02.002.

4. Abitol J, Abitol P. The larynx: A hormonal target in: diagnosis and treatment of voice disorders $4^{\text {th }}$ ed Rubin J, Sataloff R, Korovin G. Plural Publishing, San Diego.

5. Carew L, Dacakis G, Oates J. The Effectiveness of Oral Resonance Therapy on the Perception of Femininity of Voice in Male-to-Female Transsexuals. J Voice 2007; 21: 591-603. DOI:10.1016/j.jvoice.2006.05.005.

6. Hancock AB, Krissinger J, Owen K. Voice perceptions and quality of life of transgender people. J Voice 2011; 25: 553-558. DOI:10.1016/j. jvoice.2010.07.013.

7. Gooren L. Hormone treatment of the adult transsexual patient. Horm Res 2005; 64: 31-36. DOI: 10.1159/000087751.

8. Palmer D, Dietsch A, Searl J. Endoscopic and stroboscopic presentation of the larynx in male-to-female transsexual persons. J Voice 2012; 26 117-126. DOI:10.1016/j.jvoice.2010.10.014.

9. Michel A, Mormont C, Legros JJ. A psycho-endocrinological overview of transsexualism. Eur J Endocrinol 2001; 145: 365-376.

10. Smith KP, Madison CM, Milne M. Gonadal suppressive and cross-sex hormone therapy for gender dysphoria in adolescents and adult. Pharmacotherapy 2014; 34: 1282-1297.

11. Pausewang Gelfer M, Ramsey Van Dong B. A preliminary study on the use of vocal function exercises to improve voice in male-to-female transgender clients. J Voice 2013; 27: 321-334. DOI: 10.1016/j.jvoice.2012.07.008

12. Anderson JA. Pitch elevation in trangendered patients: anterior glottic web formation assisted by temporary injection augmentation. J Voice 2014; 28: 816-821. DOI: 10.1016/j.jvoice.2014.05.002.

13. Thomas JP, MacMillan C. Feminization laryngoplasty: assessment of surgical pitch elevation. Eur Arch Otorhinolaryngol 2013; 270: 2695-2700 DOI: $10.1007 / \mathrm{s} 00405-013-2511-3$

14. Remacle M, Matar N, Morsomme D et al. Glottoplasty for male-to-female transsexualism: voice results. J Voice 2011; 25: 120-123. DOI:10.1016/j. jvoice 2009.07.004.

15. Mastronikolis NS, Remacle M, Biagini M et al. Wendler glottoplasty: an effective pitch raising surgery in male-to-female transsexuals. J Voice 2013; 27: 516-522. DOI: 10.1016/j.jvoice.2013.04.004

16. Pausewang Gelfer M, Tice RM. Perceptual and acoustic outcomes of voice therapy for male-to-female transgender individuals immediately after therapy and 15 months later. J Voice 2013; 27: 335-347. DOI:10.1016/j. jvoice.2012.07.009. 
